\title{
NURTURING CONSUMERS‘ GREEN PURCHASE INTENTION ON NATURAL DYES BATIK DURING CRAFT SHOPPING TOUR IN THE BATIK CITY OF PEKALONGAN INDONESIA
}

\author{
Wenti Ayu SUNARJO \\ Universitas Jenderal Soedirman, Purwokerto, Indonesia, \\ Universitas Pekalongan, Faculty of Engineering, Pekalongan, Indonesia, e-mail: wentiayu @unikal.ac.id \\ Vigory Gloriman MANALU \\ Universitas Jenderal Soedirman, Purwokerto, Indonesia, \\ Universitas Kuningan, Faculty of Economics, Kuningan, Indonesia, e-mail: vigoryglo@uniku.ac.id
}

Wiwiek Rabiatul ADAWIYAH*

Universitas Jenderal Soedirman, Faculty of Economics and Business, Purwokerto, Indonesia, e-mail: wiwiek.adawiyah@unsoed.ac.id

\begin{abstract}
Citation: Sunarjo, W.A., Manalu, V.G., \& Adawiyah, W.R. (2021). NURTURING CONSUMERS‘ GREEN PURCHASE INTENTION ON NATURAL DYES BATIK DURING CRAFT SHOPPING TOUR IN THE BATIK CITY OF PEKALONGAN INDONESIA. GeoJournal of Tourism and Geosites, 34(1), 186-192. https://doi.org/10.30892/gtg.34124-635
\end{abstract}

\begin{abstract}
Demand on eco-friendly products is burgeoning, as a form adaptation to climate change mitigation strategy. Hence, environmental issues are still considered as an emerging topic that concerns the tourism sector. Planned Behavior Theory (TPB) describes the formation of environmentally friendly behavior intentions in green purchase intentions of natural batik dyes. Data were obtained from 200 visitors who ever purchased natural dyed batik during their craft shopping tours to the city of Batik, Pekalongan Indonesia. The data were further analyzed using the structural equation modeling (SEM) approach. The initial model's calculation results reveal that green subjective norm has no significant relationship on green purchase intention. Furthermore, green product knowledge and attitude positively impact green purse intention of batik products made from natural ingredients. The results showed that INELOC does not moderate the relationship between attitude (ATT) on green purchase intention. Craft shopping tour is becoming popular choice of sightseeing bundling offered by travel agents. Besides its positive value, increasing demand on the handicraft shopping also has a negative consequence on the environment. The destruction occurs as a result of rapid growth in consumption, hence, purchasing environmentally friendly products can be a way to minimize the climate change and balancing the ecosystems. Demand on eco-friendly products is burgeoning, as a form adaptation to climate change mitigation strategy. Realizing that the river pollution can endanger people's health, MSMEs have started producing batik with natural dyes. Although the number of MSMEs that produce natural dyed batik products is not high, the Pekalongan City Government is continually socialize the importance of reducing chemical waste and river pollution. These findings have important implications for marketers and policymakers of natural dye batik.
\end{abstract}

Key words: handicraft shopping tour, Internal Environment Locus of Control, Green Purchase Intention

\section{INTRODUCTION}

Recently, consumer preference for environmentally friendly products is flourishing. The phenomenon of climate change and increasing global warming (Afrinaldy et al., 2017) is the driving factor for increasing public awareness of ecological problems. High level of consumption on non-environmentally friendly products globally have proliferate environmental problems which resulted as pollution in various elements of life (Afrinaldy et al., 2017) such as; water, air (Lou et al., 2017) land, and waste (De Aquim at al., 2019). Thus, the novel green consumption trend among community encourages every member to understand and alter their conventional consumption patterns in their purchase intentions in pursuing environmental sustainability (Ahmad at al., 2020; Brutting et al., 2020; De Aquim et al., 2019; Prakash et al., 2019; Jaiswal and Kant, 2018; Nie et al., 2018). Research on green products' consumer purchase intentions has been widely conducted (Chairy, 2012; Joshi and Zillur, 2015; Mobrezi and Khoshtinat, 2016; Bashir et al., 2019; Agmeka et al., 2019). Kim and Hwang (2020), in their study, explain that the intention of environmentally friendly behavior related to the theoretical framework and product knowledge about the pro-environment in terms of goods (food) delivery services using drones to reduce air pollution from goods delivery vehicles (food). Furthermore, Hsu et al. (2017), in their study on environmental knowledge, attitude, and green purchase intention, found that attitude and subjective norms significantly impact purchase intention of herbal skin care products. From the above explanation, it can be concluded that increasing public awareness of various environmental problems encourages environmentally friendly products' purchase intention. The Planned Behavior Theory (TPB) factor positively affects consumer purchase intentions (Ahmad et al., 2020). According to Hung et al. (2016), in TPB construct, subjective attitudes and norms may have the most significant and most positive effect (Wang et al., 2017). The model that will be developed in this study is consecutive with the research conducted by Guerin and Toland (2020), which is driven by TPB's concept (Ajzen, 1991) that is indirectly related to subjective norms, attitude, and knowledge. Several studies have also been modified to validate purchase intention on environmentally friendly products in accordance to the TPB concept, such as in India, where consumer attitudes and perceived behavioral control are found to be significant in predicting purchase intentions. In contrast, subjective norms did not affect (Paul et al., 2016). Another study conducted in Morocco revealed that women's traditional knowledge is ready to be integrated into natural product development (Montanari and Bergh, 2019). Eco-friendly packaging products, as a study found that purchase intention towards environmentally friendly packaging was significantly influenced by personal norms and attitudes (Prakash and Pathak, 2017). Furthermore, Hsu et al. (2017) found that attitudes, subjective norms, and perceived behavioral control significantly impact green skincare products' purchase intention in Taiwan. Based on those studies, it can be concluded that there is an insufficient number of studies on purchase intention in natural dies batik products among customers during craft shopping tour, especially in Indonesia. Previous studies on batik in Indonesia (Meutia and Ismail, 2012; Rukayah et al., 2015; Borshalina, 2015) did not focus on green buying intentions but placing higher priority on price instead. However, batik was initially made using natural dyes made from plants, which are the only available dyes in the past (Haake, 1989). Accordingly, the idea (Clean Batik Initiative (CBI), 2013) was implemented by the Indonesian - German Economic Association (EKONID). CBI aims to reduce the negative impact on the environment caused by batik production.

\footnotetext{
* Corresponding author
} 
Pekalongan is a densely-populated coastal zone, the inhabitants are hardworking as they have to cope with the risk of rob and maintain the coastal ecosystems from irresponsible acts. Many careless people trash the beach over time that would harm the seashore. Majority of the people are open minded in maintaining harmonious ecosystem. The communities have coastal zone management systems based on their traditional knowledge and practices. One of the strategy imposed by the local government in saving the environment is through consuming green products.

A study conducted by Bashir et al. (2019) found that behavioral intention towards the environment mediates the relationship between consumers' norms and green consumer behavior. Furthermore, $\mathrm{Ng}$ and Law (2015) argued that people with an internal locus of control (LOC) show a positive attitude towards environmentally friendly products. It is due to the belief that their actions are the main determinants of the environment's well-being (Basak and Ghosh, 2011). On the other hand, the result of the study on people who have an external LOC has no impact on the environment because they believe that their purchase will not make a significant environmental change. They tend to believe that this is the government's responsibility or company (Basak and Ghosh, 2011). Individuals with an internal locus of control show a better adaptation to various situations in a more practical way than people who have an external locus of control (Trivedi et al., 2015). If research that explores the impact of internal and external control beliefs on individual pro-environmental behavior, a study conducted by Yang and Weber (2019) developed and tested an integrated environment locus of control (ELOC) model. The results showed that internal ELOC produces positive effects on green behavior. Accordingly, based on the explanation above, INELOC is expected to have a moderating role in this study. Patel et al. (2020) constructed a model in their study which connects internal consumer trends (identity and internal environmental control locus) with the development of TPB to determine green purchase intention. Although the results were consistent with the theoretical basis and supported by empirical evidence, the study limitations suggest further research on more specified green products - this study identified as MSME batik products that use natural dyes in Pekalongan City, Indonesia.

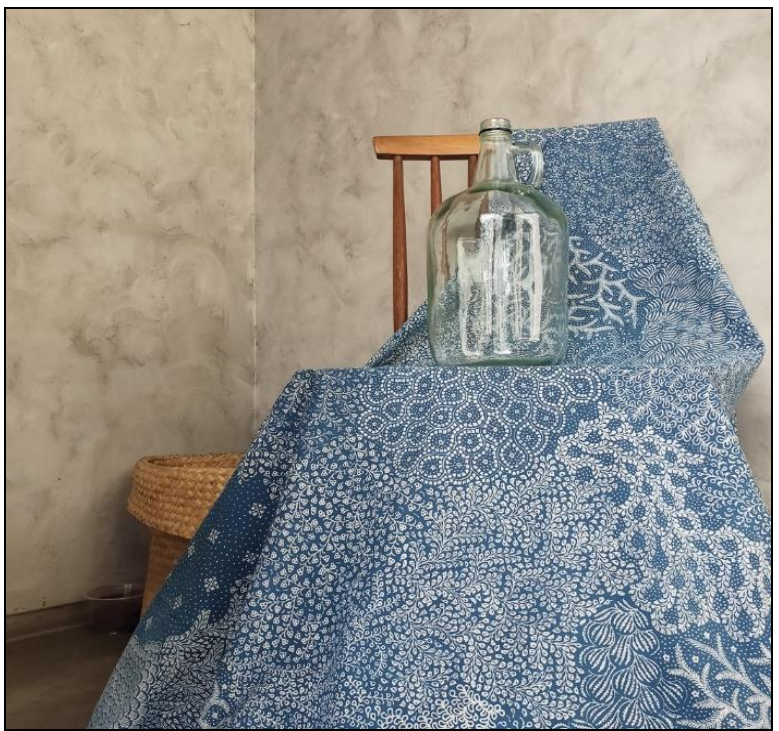

Figure 1. Natural Dyed Batik (Indigo)

(Sources: Zahir Widadi Batik Pekalongan, 2020)

The current orientation of the international market is that batik is agreeable to nature (Clean Batik Initiative/CBI, 2013). This is focused on the fact of the detrimental effects of the improper use of synthetic dye based chemicals in the batik industry. According to the Water Resources Management Agency (BPSDA), the four rivers in Pekalongan have been polluted and can no longer be used on a municipal or community basis. Rain water can no longer be used for watering rice fields or fishing ponds in delta rivers. Given the degree to which this issue is significant and the lack of viable solutions to solve it, CBI finds the use of natural dyes to be a very important idea to enable the industry to recover its roots and to be able to contribute to sustainable growth. A great deal of re-learning is needed to achieve this goal (Clean Batik Initiative/CBI, 2013). On 2 October 2009, Batik was copyrighted by the United Nations Educational, Science and Cultural Organization (UNESCO) as a human heritage for non-material oral culture (Masterpieces of the Oral and Intangible Heritage of Humanity) originating in and belonging to Indonesia. Thus the town of Pekalongan, which is one of the most popular areas for the batik industry in Indonesia, is closely linked to the culture of the Batik manufacturing process. According to the Pekalongan City Department of Industry, Trade, Cooperatives and Micro, Small and Medium Enterprises (MSMEs), Pekalongan has been declared a national batik hub, with $70 \%$ of the batik supply in Indonesia coming from the city. The Department of Industry, Trade, Cooperatives and Micro, Small and Medium Enterprises

(UMKM) of Pekalongan City also reported that over time the City of Pekalongan is trying to meet the global market needs of environmentally friendly goods. The idea of manufacturing naturally dyed batik has been warmly accepted by the international market for its inspiration to manufacture environmentally sustainable batik products. The goal of this study is to explore the relationship between green subjective standards, awareness of green products and attitudes towards green purchasing intentions through the Internal Environmental Control Locus (INELOC) between craft shopping tourists in the Batik town of Pekalongan.

\section{LITERATURE REVIEW}

\section{Theory of Reasoned Action (TRA) and Theory Planned Behavior (TPB)}

Customarily, in consumer behavior research, it is started by (Ajzen and Fishbein, 1977), Theory of Reasoned Action (TRA), which explains that consumer behavior is determined by intention, combined with subjective attitudes and norms. Furthermore, the theory of planned behavior (TPB), according to Ajzen and Fishbein (1980), is used as an extended TRA model consisting of perceived behavioral control with norm attitudes and actions. TPB is a theory developed based on the theory of reasoned action (TRA) and can be interpreted as an indication of a person's readiness to behave in a particular pathway (Ajzen, 1991). Thus TPB incorporates perceived behavioral control (PBC) into TRA. Perceived behavioral control implies an individual's perception of readiness and ability to engage in certain activities (Ajzen, 2000; Wu, J. M., 2016). It is subsequent with Guerin and Toland's (2020) study results where the overall findings correspond to the TPB. The findings supported the incorporation of the behavior theory (especially the TPB modification theory). Our environmental theory is developed based on TPB by combining green subjective norms, knowledge of green products, and attitudes with an internal locus of control (INELOC) in predicting green behavior intentions.

\section{Green Subjective Norm on Green Purchase Intention}

Subjective norms can be understood as the perceived social power to perform certain behaviors (Ajzen, 1991). According to Ajzen's theory, the factors that can influence the cognitive-affective process are the subjective norms determined by a person's normative beliefs on whether essential people (such as friends, parents, teachers, and coworkers) agree or disagree with the behavior and the pers on's willingness to comply with others. Thus indicates the importance of people's judgments one's behavior decision (Ajzen, 1991). The emergence of green subjective norms (GSN) stems from the theory of planned behavior (TPB) by combining independent self-construal and interdependent selfconstrual into a planned behavior theory (TPB) adjustment. The merger was carried out to predict green behavioral intention (Ajzen, 1991; Ajzen and Fishbein, 1977; Mancha and Yoder, 2015). Furthermore, in their research, Mancha and Yoder (2015) found that carrying out a campaign to promote green behavior prioritizes independence, precisely aims to support attitudes of preservation, and campaigns that focus on interdependence must specifically improve subjective green norms and perceived behavioral control. Once this 
self-evaluation is fulfilled, the requirements of attention to the dissonance between increased attitudes and beliefs should result in adopting greener intentions and behaviors. Thus it can be concluded that green subjective norm has a significant and positive relationship with green behavioral intention. Therefore, it is suggested that the antecedents of green behavioral intentions will have a positive relation to intended green behavior. The proposed hypothesis can be stated as follows:

Hypothesis 1: Green subjective norm can influence green purchase intention.

\section{Knowledge of Green Product on Green Purchase Intention}

The result of the study conducted by Guerin and Toland (2020) supported TRA. The structural equation models fit the data well, most of the path coefficients are significant, and knowledge has an indirect effect on behavioral intention. Hair et al. (2006) stated that a relationship between knowledge about products and green purchase intentions, while knowledge on usage and purchase has no relationship. Contrary, the findings of Choi and Johnson (2019) stated that environmental knowledge has a considerable effect in explaining purchase intention. Previous research on consumer experiences in using products has proven that there are differences between expectations and perceptions in determining consumer attitudes (Souri et al., 2018). Similarly, the results of other previous studies on the quality of knowledge cost knowledge, and knowledge of green products affect green purchase intention (Wang and Hazen, 2016). Furthermore, environmental knowledge is proven to have a positive relationship with green purchase intention (Zhao and Zhong, 2015). However, Ritter et al. (2015) stated that a lack of consumer information often resulted in behavior and attitudes gaps between the environment, concerns, and actual purchase intentions. Meanwhile, another study shows no significant relationship between green consumers' knowledge and behavior (Zhao et al., 2014). Thus, it can be concluded that green behavioral intention will positively related to green behavior. The proposed hypothesis can be stated as follows;

Hypothesis 2: The knowledge of green products can influence the green purchase intention.

\section{Attitude on Green Purchase Intention}

Understanding attitudes (ATT), according to Ajzen (1991) and Ajzen and Fishbein (1977), is the level of a person's positive or negative attitude as a tendency to consistently respond to things that are favorable or unpleasant to the behavior target. Research conducted by Verma (2018) created a socio-psychological model that was developed by including original variables rooted in TPB, and the findings showed that attitude ranked the highest in the results achieved to predict consumers' purchase intention of green products. Furthermore, Hung et al. (2016) stated that the right attitude and purchase intention are positively related to consumers' attitudes. Similarly, Leonidou et al. (2010) examined how individuals evaluate various pro-environmental actions by proposing two constructs; inward environmental attitude and outward environmental attitude, where the individual's role in preserving the environment is entirely dependent on the individual's efforts in it. Furthermore, the research model developed by Trivedi et al. (2018) measured the main antecedents (attitude) of environmental attitudes, which were divided into inward and outward orientation. The study found that green packaging's environmental attitudes and attitudes play an essential role in shaping green purchase intention. Therefore, the proposed hypothesis can be stated as follows;

Hypothesis 3: attitudes has a positive influence green purchase intention.

\section{Internal Environment Locus of Control (INELOC) on Green Purchase Intention}

Locus of control (LOC) refers to "a person's belief in his ability to control events that occur in his life," which was first proposed by Rotter (1960). It is generally believed that people with an internal LOC show a positive attitude towards the use of environmentally friendly products. They believe that their actions are a significant determinant of environmental well-being. On the other hand, those with an external LOC will show learned helplessness because they believe that their purchase will not make a significant environmental change and argued that it is the government or companies (Trivedi et al., 2015). Psychological surveys of the environment found that internal locus of control is one of the strongest predictors of individuals (Sebastian ang Guido, 2007). Yang and Weber (2019) stated that respondents perceived higher responsibility given to government and companies relative to their environmental impacts driven by Confucian values (i.e., group orientation, belief in the hierarchy) with relatively consistent internal ELOC compared to external ELOC. Ahn et al. (2014) discussed the implications of using embodied experiences for behavior change with an internal environment locus of control (INELOC) serving as a moderator. It served as the rationale for the argument that people with INELOC have greater involvement in consuming environmentally friendly products than people with external LOCs (Schwepker Jr and Cornwell, 1991). Overall, because it has been found that the relationship between attitudes towards the environment and LOC is clearly established in both individualism and collectivism societies, this study considers this to be an INELOC variable (Patel et al., 2020). According to Bashir et al. (2019), behavioral intention towards the green environment moderates the positive and significant relationship between consumer norms and green consumer behavior. Furthermore, internal locus of control (LOC) shows a positive attitude towards the use of environmentally friendly products, which is the main modal for influencing the purchase intention of environmentally friendly products, driven by the belief that their actions are the main determinants of environmental welfare.

However, those with an external LOC tend to believe that the purchase they made will not significantly change the environment. The responsibility is the government or company (Trivedi et al., 2015). Companies are more likely to support such campaigns as part of their corporate social responsibility (Parsa, 2011). The concept of locus of control was initiated by Rotter (1960), defined as an individual's control over their work and their belief in self-success, which divided into two; first, the internal locus of control that explains a personal belief on the self-responsibility for their work behavior in the organization. Second, external locus of control describes individuals who believe that their work behavior and their success are more due to external factors, such as the organization. Locus of control can also be demonstrated by two essential characteristics; high achievement motivation and low external direction. It is believed to be the basis of the locus of control scale. Furthermore, it has been revealed that a person's feelings can control his life goals, which is an integral and essential correlation of health (Rotter, 1960). The presence of INELOC is argued to have strengthened the effect of green subjective norm, knowledge of green products, and attitudes towards the intention to purchase green products as a moderating factor (Patel et al., 2020). According to Suliyanto (2011), the moderating variable is a variable that determines or affects the strength or weakness of the relationship between the independent variable and the dependent variable.

The moderator or contingency variable is a variable that has a contingent effect. A study conducted by Patel (2020) used INELOC as a moderating variable on the relationship between ATT and purchase behavior control (PBC) on GPI. It has never been used as a moderating variable on the relationship between GSN, KGP, and ATT on GPI. Therefore, the proposed hypothesis can be stated as follows;

Hypothesis 4: Ineloc moderates the influence of green behavior norms and green purchase intention.

Purchasing green products is personal behavior that can be manipulated through information and emotional processes. Ghahtarani et al. (2020) argued that sharing knowledge can impact purchase intentions because by having the information about products and services, one can make wise decisions about which product will be purchased. Furthermore, internal locus of control (ILOC) is highlighted as an essential determinant of behavior among consumers, where consumers with high INELOC have a more favorable attitude towards products 
(Patel et al., 2020). The study was supported by TPB's basic concept, which was developed in predicting consumer knowledge of green products (Knowledge of Green Products) on green purchase intentions. Similar to the research conducted by Deijen and Kornaat (1997), the results show that emphasizing additional information on product users is very important because it can increase user knowledge, increase short-term compliance, and increase long-term knowledge of the product used. Therefore, the proposed hypothesis can be stated as follows;

Hypothesis 5: Ineloc moderates the influence on knowledge of green products and green purchase intention.

Attitude is a psychological tendency expressed by evaluating specific goals through several levels ranged from the most liked to disliked (Eagly and Chaiken, 1993). Previous studies' support that attitudes toward the environment as the most relevant and vital determinant of proenvironmental behavior intentions (Kai and Haokai, 2016). Consistently, a research by Deijen and Kornaat (1997) indicated that the internal locus of control views behavior as internal motivation that helps someone to achieve self-determined goals related to the individual's (positive or negative) attitude. Therefore, this study proposes that the internal environment of locus of control (INELOC) to have a moderating effect on green products' knowledge. According to the study conducted by Patel et al. (2020), using samples of respondents at a productive age resulted in the significant influence of attitude on the intention to purchase green products. Therefore, the proposed hypothesis can be stated as follows;

Hypothesis 6: Ineloc moderates the effect of attitudes on green purchase intention.

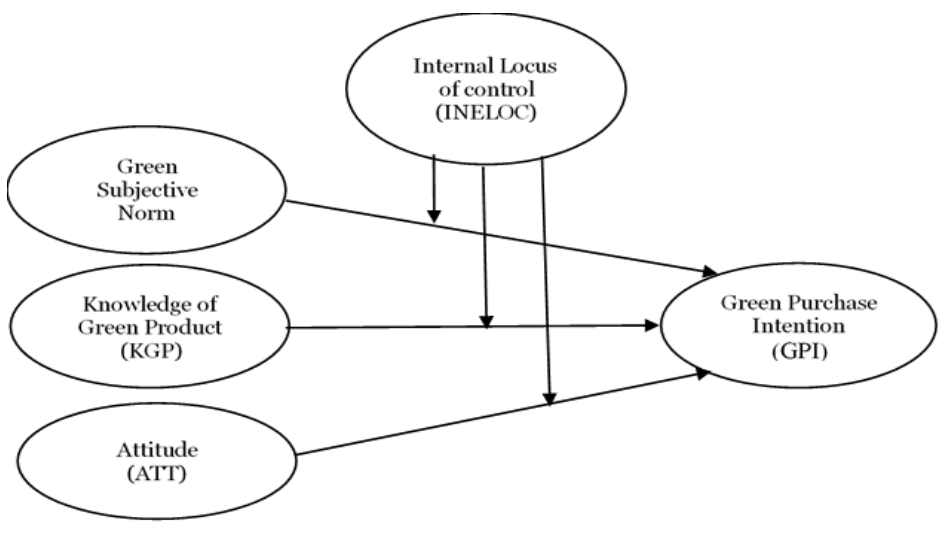

Figure 2. Research Framework (Source: Authors' model developed for the study)
Table 1. Characteristic Respondents (Source: primary data obtained through questionaires)

\begin{tabular}{|l|l|c|c|}
\hline Demographics & Categories & Frequency & Percent \\
\hline Gender & Males & 82 & 41 \\
& Females & 118 & 59 \\
Total & & $\mathbf{2 0 0}$ & $\mathbf{1 0 0 . 0}$ \\
Education & Doctoral & 7 & 3.5 \\
Background & Master & 63 & 31.5 \\
& Degree & 91 & 45.5 \\
Total & High School & 39 & 19.5 \\
Profession & & $\mathbf{2 0 0}$ & $\mathbf{1 0 0 . 0}$ \\
& Governance & 20 & 10 \\
& Lecturer & 54 & 27 \\
& Entrepreneurs & 42 & 21 \\
& Employee & 36 & 18 \\
Total & Student & 15 & 7.5 \\
& Others & 33 & 16.5 \\
& & $\mathbf{2 0 0}$ & $\mathbf{1 0 0 . 0}$ \\
\hline
\end{tabular}

\section{MATERIALS AND METHODS}

\section{Participant and Sampling Design}

According to circumstances, the sampling method involved a stratification process, followed by Stratum subjects' random selection. The sample population mentioned above was taken from the residence of Central Java, who is familiar with Pekalongan batik products, especially natural dyed batik products. The sampling technique used a purposive sampling method with certain criteria; the respondents were people who had bought natural dyed batik. According to Patton (1990), the tendency of purposive sampling is usually used in homogeneous research cases, such as in this study. 200 respondents were gathered, 13 question items were asked and measured using a 5-point Likert scale ( 1 = strongly disagree, 2 = disagree, 3 = neutral, 4 = agree, 5 = strongly agree $)$.

\section{Descriptive Statistics}

A total of 200 respondents were gathered (Table 1); 59 percent were women, while 41 percent were men. Majority of the people come from Java island, Indonesia. The educational backgrounds differ as 3.5 percent of doctoral graduates, the majority is 31.5 percent of master graduates, holds bachelor degree 45.5 percent, 19.5 percent high school. Based on the age category, respondents with age ranged 17-34 years are 42.5 percent, $35-50$ years are 52 percent, and respondents older than 50 years are 5.5 percent. From this data, the highest number of respondents is at the age of 35-43 years. In terms of work positions, most of the respondents from this study as lecturers are 27, working in government institutions with a total of 10 percent, percent, entrepreneurs are 21 percent, employees are 18 percent, students 7.5 percent, and others are 16.5 percent.

Table 2. Mesurement, Reliability, and Validity (Source: Authors' calculation)

\begin{tabular}{|c|c|c|c|c|c|}
\hline Constructs and Indicators & Factor Loading & Composite Reliability & AVE & Mean & SD \\
\hline Green Subjective Norms (GSN) (Kim and Hwang, 2020) & & 0,756 & 0,509 & & 0,56 \\
\hline $\begin{array}{l}\text { I believe that buying environmentally friendly products (natural color batik) is a } \\
\text { good example for others }\end{array}$ & 0,733 & & & 4,2 & \\
\hline Using environmentally friendly products (natural color batik) is the right thing to do & 0,762 & & & 3,9 & \\
\hline $\begin{array}{l}\text { Family, friends, and my surroundings believe its a good thing to consume } \\
\text { environmentally friendly products (natural color batik) }\end{array}$ & 0,640 & & & 3,9 & \\
\hline Knowledge of Green Product (KGP) (Liobikienè et al., 2015) & & 0,707 & 0,550 & & 0,66 \\
\hline $\begin{array}{l}\text { Knowledge about the benefits of environmentally friendly products will affect my } \\
\text { interest in buying environmentally friendly products (batik of natural dye) }\end{array}$ & 0,824 & & & 4,3 & \\
\hline $\begin{array}{l}\text { I know the price of environmentally friendly products (batik of natural dye) is more } \\
\text { expensive than chemical batik products }\end{array}$ & 0,649 & & & 4,1 & \\
\hline Attitude (ATT) (Mancha and Yoder, 2015) & & 0,763 & 0,616 & & 0,68 \\
\hline I started to leave products that are not environmentally friendly & 0,779 & & & 4,1 & \\
\hline I would encourage everyone to use environmentally friendly products & 0,791 & & & 4,2 & \\
\hline Internal Environment Locus of Control (INELOC) (Patel et al., 2020) & & 0,848 & 0,653 & & 0,67 \\
\hline I use environmentally natural color batik as a form of self-respect to the green peace & 0,833 & & & 4,4 & \\
\hline The environment that made me become a loyal consumer of natural color batik & 0,712 & & & 4,1 & \\
\hline I support the go green movement which is being encouraged by my government & 0,87 & & & 4 & \\
\hline I am interested in buying natural color batik because the trend is updated & 0,893 & & & 3,8 & \\
\hline I bought natural color batik products to safe the environment regardless the price & 0,86 & & & 3,4 & \\
\hline I bought natural color products because of the pressure to preserve the environment & 0,891 & & & 3,4 & \\
\hline
\end{tabular}




\section{RESULTS AND DISCUSSION}

Confirmation factor analysis (CFA) was conducted to test the validity of the measurement model with data. In total, the resul ts indicate that the measurement model has met the appropriate statistical criteria. CMIN / DF is 1.251 , probability 0.100, AGFI 0.918, GFI 0.950, TLI 0.980 and RMSEA 0.036. Furthermore, the CR value of green purchase intention has a value of 0.913 , internal environmental locus of control (INELOC) 0.848, attitude 0.763, green subjective norm 0.756, knowledge of green product (KGP) 0.707 . The average variance extracted (AVE) value for each variable is above 0.5 and the loading factor value is also above 0.5 with a significance at the $5 \%$ level, the results are in accordance with an adequate increase in indicators (Bagozzi and Yi, 1988), (Table 2).

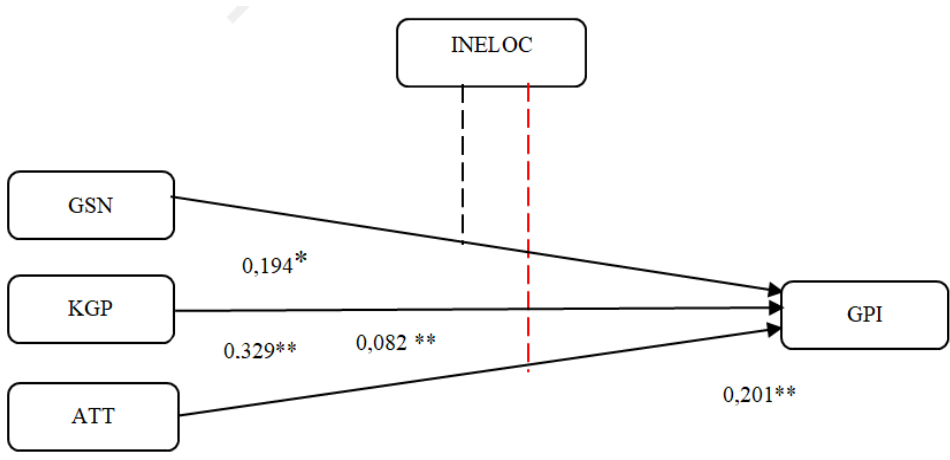

Figure 3. Moderating effects (Source: Authors' calculation) Note: Significant $<0,01^{* *}$

\section{Testing Effects}

The initial model's calculation results reveal that green subjective norm has no significant relationship on green purchase intention. Furthermore, green product knowledge and attitude positively impact green purse intention of batik products made from natural ingredients. These results need to be carried out to test the moderating effect of the internal environment locus of control (INELOC) in the relationship between green purchase intention and its antecedences.

\section{Moderating Effects}

The data were further analyzed using the structural equation modeling (SEM) approach. SEM analysis is the right tool to test our research theory, consistent with the study conducted by Hair et al. (2006). In the test, the moderating effect of internal environment locus of control (INELOC) in the relationship of attitude (ATT) on green purchase intention (GPI) was not supported with a p-value > $0.05(\beta=0.082)$. Furthermore, the moderating effect of the internal environment locus of control (IN LOC) of KGP interaction on GPI was found to be positive and significant with a p-value $<0.01(\beta=0.194)$, indicating that the relationship between green product knowledge is significantly stronger when the internal locus of control is higher (Figure 2).

\section{DISCUSSION}

One of the main problems experienced by Pekalongan City lately is environmental distruction, especially river pollution which is thought to be caused by the textile industry and the batik industry. Seeing the problem of waste that pollutes the river will endanger public health, one of which is when consuming clean water for residents around the polluted area, then with these complex problems the MSMEs start producing batik with natural dyes even though the number of MSMEs producing natural dyed batik products is not too much However, the Pekalongan City Government continues to disseminate it to this day with the hope of reducing chemical waste and river pollution which causes the river to become colorful..In addition to environmental problems, in order to meet market orders regarding the booming natural dies, the international demand for natural dye batik products is also a factor for MSME batik to produce natural dye batik. With the hope that all stakeholders can work together in promoting and disseminating environmentally friendly batik products. With the description above, then this study aims to examine the influence of green subjective norm (GSN), knowledge of green product (KGP), and attitude (ATT) on the surrounding community who buy natural dyed batik products with internal environment locus of control (INELOC) as moderator. Ajzen and Fishbein (1977) stated that attitudes, based on TPB, are stable predictors of green behavior (Prakash and Pathak, 2017). The hypothesis testing results indicate that the first hypothesis is not supported, where the purchase intention of consumers in this study is not influenced by GSN (Mobrezi and Khoshtinat, 2016). This result is different from most of the previous research results, which found a significant effect of subjective norms on purchase intention on environmentally friendly products (Talal Al-Maghrabi, 2011; Choi and Johnson, 2019). It indicates that consumers have low subjective norms so that it does not affect the purchase intention of natural dyes batik products. It can be seen from the results that the relationship between GSN is not significant (0.03). Therefore, GSN, an external factor, does not affect consumer intentions to buy natural dyes products.

However, the second and third hypotheses are supported. It is found that KGP largely determines the influence of pro-environmental behavior. This result is consistent with previous studies (Zhao and Zhong, 2015; Hung et al., 2016). When consumers have sufficient knowledge about green products, they will tend to buy natural dyes products without encouragement from the surrounding environment. Furthermore, the results showed that high ATT led to their intention to consume green products (Hung et al., 2016). These results are explained by the significant effect of ATT on GPI (0.201). The findings prove that green knowledge is necessary for creating a sustainable impact, then a high caring attitude towards environmental conservation is needed. Thus it has a substantial impact on the purchase intention of natural dyes batik products. The moderating role of INELOC on the purchase intention of natural dyes batik products indicated from the fourth and fifth hypotheses, which are equally supported, the GSN and KGP on the GPI shows significant results $(<0.05)$. It means that high GSN and KGP affect green purchase intention with the support of substantial internal factors. Awareness of GSN and the high level of KGP can be used to form further proenvironmental intentions with a strong push from the influence of their internal environment, which results in the purchase intention of natural dyes batik products. The findings indicate different results from the research conducted by Patel et al. (2020) on the relationship between ATT and GPI. The hypothesis is unsupported, where ATT had no significant effect $(0.082)$ on the purchase intention of natural dyes batik products moderated by INELOC (Figure 3). It is caused by the different attitudes that each consumer has depending on the green environment's morality and awareness. The argument consistent with Verma's (2017) study that consumers have a significant effect on positive attitudes towards the purchase intention of green products and their concern for the environment depends on morality and consciousness. Thus, it can be concluded that the findings show that attitude is not the main reason motivates consumers to buy natural dyes batik products. The awareness of each consumer in relation to self-morality motivates the decision to purchase natural dyes products that are related to environmental awareness.

\section{CONCLUSION}

This work has extended the theory of planned behavior to the field of handicraft shopping tour by proposing a framework for understanding how green subjective norm (GSN), knowledge of green product (KGP), and attitude (ATT) affect tourist intention to buy green products.

The green product in this case is a natural dye batik produced by MSMEs in the batik city of Pekalongan. Out of the six hypotheses, only two were supported (the second and third hypotheses). Knowledge on green products influence consumers' pro-environmental behavior. When they have good knowledge of green products, they tend to buy natural dyes, even without the pressure from their environmental. 
Furthermore, Attitude has a significant effect green purchase intention. Caring towards environmental preservation substantially impact the purchase intention of natural dyes batik products. The moderating role of INELOC only strengthens the relationship between knowledge on green products and green purchase intentions of customers during craft shopping tour. High subjectivity norms drive people to buy environmentally friendly batik products (natural dye batik).

It means that they wanted to be good examples for the community, especially when environmentally friendly products are consistent. One of the main problems currently faced by Pekalongan City is environmental problems, especially river pollution, which is caused by the textile industry and the batik industry waste. Realizing that the river pollution can endanger people's health, MSMEs have started producing batik with natural dyes. Although the number of MSMEs that produce natural dyed batik products is not high, the Pekalongan City Government is continually socialize the importance of reducing chemical waste and river pollution.

\section{Acknowledgement}

The author is grateful for the support provided by Universitas Jenderal Soedirman and to all respondents who were voluntary participated in the survey.

\section{REFERENCES}

Afrinaldy, F., Taufik, Tasman, A.M., Zang, H.C., \& Hasan, A. (2017). Minimizing economic and environmental impacts through an optimal preventive replacement schedule: Model and application. Journal of Cleaner Production, 143, 882-893. https://doi.org/10.1016/j.jclepro.2016.12.033

Agmeka, F., Wathoni, R.N., \& Santoso, A.S. (2019). The Influence of Discount Framing towards Brand Reputation and Brand Image on Purchase Intention and Actual Behaviour in e-commerce. The Fifth Information Systems International Conference 2019, 161, 851-858. https://doi.org/10.1016/j.procs.2019.11.192

Ahmad, W., Kim, W.G., Anwer, Z., \& Zhuang, W. (2020). Schwartz personal values, theory of planned behavior and environmental consciousness: How tourists' visiting intentions towards eco-friendly destinations are shaped? Journal of Business Research, 110, 228-236. https://doi.org/10.1016/j.jbusres.2020.01.040

Ahn, S.J.G., Bailenson, J.N., \& Park, D. (2014). Short-and long-term effects of embodied experiences in immersive virtual environments on environmental locus of control and behavior. Computers in Human Behavior, 39, 235-245. https://doi.org/10.1016/j.chb.2014.07.025

Ajzen, I., \& Fishbein M. (2000). Attitudes and the attitude-behavior relation: Reasoned and automatic processes. European Review of Social Psychology, 11(1), 1-33. https://doi.org/10.1080/14792779943000116

Ajzen, Icek; Fishbein, Martin (1977). Attitude-behavior relations: A theoretical analysis and review of empirical research. Psychological Bulletin, 84(5), 888918. https://doi:10.1037/0033-2909.84.5.888

Ajzen, I. (1991). The theory of planned behavior. Organizational Behavior and Human Decision Processes, 50(2), 179-211. https://doi.org/10.1037/0033-2909.84.5.888

Ajzen, I., \& Fishbein, M. (1980). Understanding attitude and predicting social behavior. Englewood Cliffs.

Bagozzi, R., \& Yi, Y. (1988). On The Evaluation of Structural Equation Models. Journal of the Academy of Marketing Sciences, 16, 74-74. https://doi.org/10.1007/BF02723327

Basak, R., \& Ghosh, A. (2011). School Environment and Locus of Control in Relation to Job Satisfaction among School Teachers \pm A Study from Indian Perspective. International Conference on Education and Educational Psychology (ICEEPSY 2011), 29, 1129-1208. https://doi.org/10.1016/j.sbspro.2011.11.354

Bashir, S., Khwaja, G.M., Turi, A.J., \& Toheed, H. (2019). Extension of planned behavioral theory to consumer behaviors ingreen hotel. Heliyon 5, https://doi.org/10.1016/j.heliyon.2019.e02974

Borshalina, T. (2015). Marketing Strategy and the Development of Batik Trusmi. Procedia - Social and Behavioral Science, 169, 2014. https://doi.org/10.1016/j.sbspro.2015.01.305

Brutting, J., Vandervaeren, C., Senatore, G., Temmerman, N.D., \& Fivet, C. (2020). Environmental impact minimization of reticular structures made of reused and new elements through Life Cycle Assessment and Mixed-Integer Linear Programming. Energy and Buildings, $215,109827$. https://doi.org/10.1016/j.enbuild.2020.109827

Chairy (2012). Spirituality, Self Transcendence, and Green Purchase Intention in College Students. The 2012 International Summer Conference on Business Innovation \& Technology Management, 57, 243-246. https://doi.org/10.1016/j.sbspro.2012.09.1181

Choi, D., \& Johnson, K.K. (2019). Influences of environmental and hedonic motivations on intention to purchase green products: An extension of the theory of planned behavior. Sustainable Production and Consumption, 18, 145-155. https://doi.org/10.1016/j.spc.2019.02.001

De Aquim, P.M., Hansen, E., \& Gutterres, M. (2019). Water reuse: An alternative to minimize the environmental impact on the leather industry. Journal of Environmental Management, 230, 456-463. https://doi.org/10.1016/j.jenvman.2018.09.077

Deijen, J.B., \& Kornaat, H. (1997). The influence of type of information, somatization, and locus of control on attitude, knowledge, and compliance with respect to the triphasic oral contraceptive Tri-Minulet@. Contraception, 56(1), 31-41. https://doi.org/10.1016/S0010-7824(97)00071-1

Eagly, A.H., \& Chaiken, S. (1993). The Psychology of Attitudes. Harcourt, Brace, \& Janovich, Fort Worth, TX.

Ghahtarani, A., Sheikhmohammady, M., \& Rostami, M. (2020). The impact of social capital and social interaction on customers' purchase intention, considering knowledge sharing in social commerce context. Jounal of Innovation and Knowledge, 5, 190-198. https://doi.org/10.1016/j.jik.2019.08.004

Guerin, R.J., \& Toland, M.D. (2020). An application of a modified theory of planned behavior model toinvestigate adolescents' job safety knowledge, norms, attitude andintention to enact workplace safety and health skills. Journal of Safety Research, 72, 189-198. https://doi.org/10.1016/j.jsr.2019.12.002

Haake, A. (1989). The Role Of Symmetry In Javanese. Computers Math. Applic, 17(4-6), 815-826. https://doi.org/10.1016/0898-1221(89)90262-9

Hair, F.J., Black, W.C., Babin, B.J., Anderson, R.E., \& Tatham, R.L. (2006). Multivariate data analysis. (6th ed), 5, Upper Saddle River, NJ: Prentice hall.

Hsu, C.L., Chan, C.Y., \& Yansritakul, C. (2017). Exploring purchase intention of green skincare products using the theory of planned behavior: Testing the moderating effects of country of origin and price sensitivity. Journal of Retailing and Consumer Services, 34, 145-152. https://doi.org/10.1016/j.jretconser.2016.10.006

Hung, Y., Kok, T.M., \& Verbeke, W. (2016). Consumer attitude and purchase intention towards processed meat products with natural compounds and a reduced level of nitrite. Meat Science, 121, 119-126. https://doi.org/10.1016/j.meatsci.2016.06.002

Jaiswal, D., \& Kant, R. (2018). Green purchasing behaviour: A conceptual framework and empirical investigation of Indian consumers. Journal of Retailing and Consumer Services, Elsevier, 41(C), 60-69. https://doi.org/10.1016/j.jretconser.2017.11.008

Joshi, Y., \& Zillur, R. (2015). Factors Affecting Green Purchase Behaviour and Future Research Directions. International Strategic Management, 128-143. https://doi.org/10.1016/j.ism.2015.04.001

Kai, C., \& Haokai, L. (2016). Factors affecting consumers' green commuting. Eurasia J. Math. Sci. Technol. Educ. 12 (3). https://doi.org/10.12973/iser.2016.2001a

Kanchanapibul, M., Lacka, E., Wang, X., \& Chan, H.K. (2014). An empirical investigation of green purchase behaviour among the young generation. Journal of Cleaner Production, 528-536. https://doi.org/10.1016/j.jclepro.2013.10.062

Kim, J.J., \& Hwang, J. (2020). Merging the norm activation model and the theory of planned behavior inthe context of drone food deli very services: Does the level of productknowledge really matter? Journal of Hospitality and Tourism Management, 42, 1-11. https://doi.org/10.1016/j.jhtm.2019.11.002

Kusumawati, H. (2020). Zahir Widadi Fine batik for an intricate blue world. Retrieved November 18, 2020. https://garlandmag.com/article/widadi/

Leonidou, L., Leonidou, C., \& Kvasova, O. (2010). Antecedents and outcomes of consumer. Journal of Marketing Management, 26 1319-1344. https://doi.org/10.1080/0267257X.2010.523710

Liobikienè, G., Mandravickaitė, J., \& Bernatonienė, J. (2016). Theory of planned behavior approach to understand the green purchasing behavior in the EU: A cross-cultural study. Ecological Economics, 125, 38-46. https://doi.org/10.1016/j.ecolecon.2016.02.008

Liu, Y., Hong, Z., Zhu, J., Yan, J., Qi, J., \& Liu, P. (2018). Promoting green residential buildings: Residents' environmental attitude, subjective knowledge, and social trust matter. Energy Policy, 112, 152-161. https://doi.org/10.1016/j.enpol.2017.10.020

Lou, Y., Wang, W., \& Yang, X. (2017). Customers' attitude on new energy vehicles' policies and policy impact on customers' purchase intention. The 8th International Conference on Applied Energy - ICAE2016, 105, 2187 - 2193. https://doi.org/10.1016/j.egypro.2017.03.617 
Mancha, M.R., \& Yoder Carol R. (2015). Cultural antecedents of green behavioral intent: An Environmental Theory Of Planned Behaviour. Journal of Environmental Psychology. 43, 145-154. https://doi.org/10.1016/j.jenvp.2015.06.005

Meutia, \& Ismail, T. (2012). The Development of Entrepreneurial Social Competence And Business Network to Improve Competitive Advantage And Business Performance of Small Medium Sized Enterprises: A Case Study of Batik Industry In Indonesia. International Congress on Interdisciplinary Business and Social Sciences 2012 (ICIBSoS 2012), 65, 46-51. https://doi.org/10.1016/j.sbspro.2012.11.089

Mobrezi, H., \& Khoshtinat, B. (2016). Investigating the factors affecting female consumers' willingness toward green purchase based on the model of planned behavior. Procedia Economics and Finance 36, 441 - 447. https://doi.org/10.1016/S2212-5671(16)30062-4

Montanari, B., \& Bergh, S.I. (2019). Why women's traditional knowledge matters in the production processes ofnatural product development: The case of the Green Morocco Plan. Women's Studies International Forum 77, 102275. https://doi.org/10.1016/j.wsif.2019.102275

Nie, S., Huang, Z., Huang, G., Yu, L., \& Liu, J. (2018). Optimization of electric power systems with cost minimization and environmental-impact mitigation under multiple uncertainties. Applied Energy, 221, 249-267. https://doi.org/10.1016/j.apenergy.2018.03.194

Ng, M., Law, M., 2015. Encouraging green purchase behaviours of Hong Kong consumers. Asian Journal Business Research, 5 (2), 1-18. https://doi.org/10.14707/ajbr.150013

Parsa, P.K. (2011). Factors associated with breast self examination-among malaysia women teachers. East. Mediterr. Health, 17(6), 509-516. https://doi.org/10.26719/2011.17.6.509

Patel, J.D., Trivedi, R.H., \& Yagnik, A. (2020). Self-identity and internal environmental locus of control: Comparing their influences on green purchase intentions in high-context versus. Journal of Retailing and Consumer Services, 53, 102003. https://doi.org/10.1016/j.jretconser.2019.102003

Patton, M.Q. (1990). Qualitative evaluation and research methods. (2. Edition) Newbury Park, CA, Sage Publications.

Paul, J., Modi, A., \& Patel, J. (2016). Predicting green product consumption using theory of planned behavior and reasoned action. Journal of Retailing and Consumer Services, 23, 123-134. https://doi.org/10.1016/j.jretconser.2015.11.006

Prakash, G., \& Pathak, P. (2017). Intention to buy eco-friendly packaged products among young consumers of India: A study on developing nation. Journal of Cleaner Production, 141, 385-393. https://doi.org/10.1016/j.jclepro.2016.09.116

Prakash, G., Sangita, C., Kumar, A., Garza-Reyes, J.A., Khan, S.A., \& Panda, T.K. (2019). Do altruistic and egoistic values influence consumers' attitudes and purchase intentions towards eco-friendly packaged products? An empirical investigation. Journal of Retailing and Customer Services, 50, 163-168. https://doi.org/10.1016/j.jretconser.2019.05.011

Ritter, A.M., Borchardt, M., Vaccaro, G.L., Pereira, G.M., \& Almeida, F. (2015). Motivations for promoting the consumption of green products in an emerging country: exploring attitudes of Brazilian consumers. Journal of Cleaner Production, 106, 507-520. https://doi.org/10.1016/j.jclepro.2014.11.066

Rotter, J.B., (1960). Some implications of a social learning theory for the prediction of goal directed behavior from testing procedures. Psychological Review 67 (5), 301. https://doi.org/10.1037/h0039601

Rukayah, R.S., Wibowo, A.A., \& Wahyuningrum, S.H. (2015). Public Participation in Branding Road Corridor as Shopping Window or Batik Industry at Pekalongan. Procedia Social and Behavioral Science, 168, 76-86. https://doi.org/10.1016/j.sbspro.2014.10.212

Sebastian, B., \& Guido, M. (2007). Twenty years after Hines, Hungerford, and Tomera: A new meta-analysis of psycho-social determinants of proenvironmental behaviour. 27(1), 14-25. https://doi:10.1016/j.jenvp.2006.12.002

Schwepker, Jr., C.H., \& Cornwell, T.B. (1991). An examination of ecologically concerned consumers and their intention to purchase ecologically packaged products. J. Public Policy Mark, 77-101. https://doi.org/10.1177/074391569101000205

Souri, M.E., Sajjadian, F., Sheikh, R., \& Sana, S.S. (2018). Grey SERVQUAL method to measure consumers' attitudes towards green products - A case study of Iranian consumers of LED bulbs. Journal of Cleaner Production, 177, 187-196. https://doi.org/10.1016/j.jclepro.2017.12.105

Suliyanto. (2011). Ekonometrika Terapan, Teori dan Aplikasi dengan SPSS. [Applied Econometrics, Theory and Applications with SPSS]. Yogyakarta, Andi.

Talal Al-Maghrabi, C.D. (2011). Determinants of Customer Continuance Intention of Online Shopping. Journal of Business Science and Applied Management, 6 (1), 41-65.

Trivedi, R.H., Patel, J.D., \& Acharya, N. (2018). Causality analysis of media influence on environmental attitude, intention and behaviors leading to green purchasing. Journal of Cleaner Production, 196, 11-22. https://doi.org/10.1016/j.jclepro.2018.06.024

Trivedi, R., Patel, J., \& Savalia, J. (2015). Pro-environmental behaviour, locus of control aand willingness to pay for environmental friendly products. Marketing Intelligence \& Planning, 33(1), 67-89. https://doi.org/10.1108/MIP-03-2012-0028

Verma, V.K. (2018). An application of theory of planned behavior to predict young indian consumers' green hotel visit intention. Journal of Cleaner Production, 172, 1152-1162. https://doi.org/10.1016/j.jclepro.2017.10.047

Wang, Y., \& Hazen, B.T. (2016). Consumer product knowledge and intention to purchase remanufactured products. International Journal of Production Economics, 181(Part B), 460-469. https://doi.org/10.1016/j.ijpe.2015.08.031

Wu, J.M. (2016). Unraveling public support for casino gaming: The case of casino referendum in Penghu. Journal of Travel \& Tourism Marketing, 34(3), 398-415. https://doi.org/10.1080/10548408.2016.1182457

Yang, X., \& Weber, A. (2019). Who can improve the environment-Me or the powerful others? An integrative approach to locus of control and proenvironmental behavior in China. Resources, Conservation \& Recycling. 146 (2019) 55-67. https://doi.org/10.1016/j.resconrec.2019.03.005

Zhao, Hui-hui; Gao, Qian; Wu, Yao-ping; Wang, Yuan; Zhu, Xiao-dong (2014). What affects green consumer behavior in China? A case study from Qingdao. Journal of Cleaner Production, 63, 143-151. https://doi.org/10.1016/j.jclepro.2013.05.021

Zhao, R., \& Zhong, Z. (2015). Carbon labelling influences on consumers' behaviour: a system dynamics approach. Ecological Indicators, 51, 98-106. https://doi.org/10.1016/j.ecolind.2014.08.030

****Clean Batik Initiative (CBI). (2013). Laporan Pencapaian Tahun 2011-2012 Tahun Kedua. jakarta: EU-Switch Asia Program.

*** UNESCO, Nomination for Inscription on the Representative List In 2009, (reference No. 00170), Intergovermental Committee For The Safeguarding of the Intangible Culture, United Arab Emirates, 28 September to 2 October 2009. https://doi.org/10.1016/j.jclepro.2017.10.047

Article history: Received: $14.10 .2020 \quad$ Revised: 24.01 .2021
Accepted: 15.02.2021

Available online: 04.03.2021 